\title{
Effect of heat on the nutritional value of lupin (Lupinus angustifolius) - seed meal for growing pigs
}

\author{
By E. S. BATTERHAM, L. M. ANDERSEN, B. V. BURNHAM \\ AND G. A. TAYLOR \\ Department of Agriculture, Agricultural Research Centre, Wollongbar, \\ New South Wales 2480, Australia
}

(Received 6 September 1984 - Accepted 2 August 1985)

\begin{abstract}
1. Two experiments were conducted to determine the effects of heat on the nutritional value of lupin (Lupinus angustifolius cv. Uniharvest and Unicrop)-seed meal, relative to soya-bean meal, for growing pigs.

2 . In both experiments, values for carcass gain/d and food conversion ratio (FCR) on a carcass basis of pigs fed on the diets containing lupin-seed meal were inferior $(P<0.05)$ to those produced by pigs fed on soya-bean meal.

3. In the first experiment, heating lupin seed at temperatures from 105 to $150^{\circ}$ for 15 min resulted in a linear depression in carcass gain/d, a quadratic increase in carcass FCR, a linear decrease in lean in the ham and a linear increase in backfat thickness. In the second experiment, autoclaving lupin seed from 5 to $45 \mathrm{~min}$ at $121^{\circ}$ resulted in a linear depression in carcass gain/d and a linear increase in carcass FCR.

4. The addition of L-lysine to the diets containing lupin-seed meal verified that lysine was limiting in both experiments. The additions of L-lysine did not overcome the differences in carcass gains/d of pigs fed on lupin-seed meal relative to those fed on diets containing soya-bean meal.

5. It is concluded that the low lysine availability in lupin-seed meal for pigs is not due to the presence of heat-labile anti-nutritional factors in the seed.
\end{abstract}

Previous work (Batterham et al. 1984) indicated low and variable lysine availability in lupin (Lupinus angustifolius)-seed meal for growing pigs. Lysine availability (proportion of total) varied from 0.37 to 0.65 (mean 0.53 ) in four samples. The low lysine availability was not due to impared digestibility as the ileal digestibility of lysine in the sample with lowest lysine availability $(0.37)$ was high $(0.86 ; \mathrm{M}$. R. Taverner, personal communication). Furthermore, the low lysine availability was specific to pigs as it was high in rats (mean 0.81 , range $0.70-0.94$; Batterham et al. 1984) and chicks (mean 0.91, range 0.81-0.95; E. S. Batterham and E. J. Major, unpublished results). The low lysine availability in pigs appeared to be due to either the lysine being digested in a form that was inefficiently utilized or to the presence of anti-nutritional factors that depressed pig performance in the slope-ratio assays.

The major proportion of lupin-seed protein is storage protein, globulins (Cerletti, 1983). The protein is deficient in the sulphur amino acids, methionine and cystine. In vitro digestibility of lupin globulins with pepsin and trypsin is less than that of casein, possibly due to the native configuration of the protein molecule, and is improved by heat (Cerletti, 1983). As a result, Cerletti (1983) concluded that both amino acid composition and reduced digestibility by proteolytic enzymes contributed to the poorer nutritional value of lupinseed protein.

Lupin seeds appear to be free of the major anti-nutritional factors, trypsin inhibitors and haemagglutinins (Hill, 1977; Hudson, 1979) and are fed without heat processing. Older 'bitter' varieties contain up to $25 \mathrm{~g}$ alkaloids $/ \mathrm{kg}$. Newer 'sweet' varieties are virtually free of alkaloids $(<0.1 \mathrm{~g} / \mathrm{kg}$ ). The meals used by Batterham et al. (1984) contained $<0.14 \mathrm{~g}$ alkaloid $/ \mathrm{kg}$ and this is unlikely to have depressed lysine availability. Other minor anti-nutritional factors in lupin seed include traces of C-glycosyl flavanol, saponins, oligosaccharides and small amounts of erucic acid in the fatty acids of some lupin species (Hudson, 1979). The modes of action of anti-nutritional factors are complex and it is 
Table 1. Expts I and 2. Composition ( $\mathrm{g} / \mathrm{kg}$ dry matter) of the major dietary components

\begin{tabular}{|c|c|c|c|c|c|c|}
\hline & \multicolumn{3}{|c|}{ Expt 1} & \multicolumn{3}{|c|}{ Expt 2} \\
\hline & $\begin{array}{l}\text { Wheat } \\
\text { (cv. } \\
\text { Condor) }\end{array}$ & $\begin{array}{c}\text { Lupin*-seed } \\
\text { meal no. 1 } \\
\text { (cv. Uniharvest) }\end{array}$ & $\begin{array}{l}\text { Soya-bean } \\
\text { meal no. } 1\end{array}$ & $\begin{array}{l}\text { Wheat } \\
\text { (cv. } \\
\text { Condor) }\end{array}$ & $\begin{array}{l}\text { Lupin-seed } \\
\text { meal no. } 2 \\
\text { (cv. Unicrop) }\end{array}$ & $\begin{array}{l}\text { Soya-bean } \\
\text { meal no. } 2\end{array}$ \\
\hline $\begin{array}{l}\text { Crude protein } \\
\quad(\text { nitrogen } \times 6 \cdot 25)\end{array}$ & 173 & 333 & 504 & 159 & 347 & 508 \\
\hline $\begin{array}{l}\text { Light petroleum } \\
\text { (b.p. } 40-60^{\circ} \text { ) extract }\end{array}$ & 15 & 64 & 19 & 21 & 47 & 31 \\
\hline \multicolumn{7}{|l|}{ Fibre } \\
\hline Crude & 28 & 179 & 72 & 28 & 172 & 48 \\
\hline Acid-detetgent & 50 & 245 & 95 & 43 & 250 & $-\dagger$ \\
\hline Neutral-detergent & 116 & 262 & 123 & 108 & 277 & 130 \\
\hline Hemicellulose & 66 & 17 & 28 & 65 & 27 & - \\
\hline Ash & 20 & 29 & 66 & 17 & 33 & 78 \\
\hline Alkaloid & - & $<0.11$ & - & - & $<0.11$ & - \\
\hline \multicolumn{7}{|l|}{ Essential amino acids } \\
\hline Threonine & $4 \cdot 8$ & 12 & 20 & $4 \cdot 5$ & 13 & 19 \\
\hline Valine & $6 \cdot 9$ & 13 & 26 & $6 \cdot 4$ & 12 & 22 \\
\hline Cystine & $3 \cdot 3$ & 7 & 5 & $3 \cdot 5$ & 6 & 10 \\
\hline Methionine & $1 \cdot 7$ & 3 & 6 & $1 \cdot 4$ & 2 & 8 \\
\hline Isoleucine & $5 \cdot 7$ & 14 & 22 & $5 \cdot 2$ & 14 & 20 \\
\hline Leucine & $11 \cdot 2$ & 27 & 39 & $9 \cdot 7$ & 27 & 32 \\
\hline Tyrosine & $5 \cdot 4$ & 12 & 20 & $4 \cdot 5$ & 12 & 20 \\
\hline Phenylalanine & $6 \cdot 7$ & 13 & 22 & $6 \cdot 4$ & 12 & 23 \\
\hline Histidine & $3 \cdot 5$ & 10 & 14 & 3.5 & 9 & 14 \\
\hline Lysine & $4 \cdot 3$ & 16 & 30 & 4.9 & 16 & 29 \\
\hline Tryptophan & - & - & - & $1 \cdot 3$ & $2 \cdot 1$ & $5 t$ \\
\hline
\end{tabular}

* Lupinus angustifolius.

$\dagger$ Not determined.

\$ Estimated value from previous assays with similar soya-bean meals.

possible that lupin-seed meal contains a factor or factors that inhibits lysine availability for pigs.

The present paper reports two experiments conducted to determine if the low lysine availability of lupin-seed meal for pigs could be overcome by the application of heat to lupin seed. In the first, the effect of applying graded amounts of dry heat from 105 to $150^{\circ}$ for $15 \mathrm{~min}$ was assessed. In the second, moist heat was applied to lupin seed at $121^{\circ}$ for periods from 5 to $45 \mathrm{~min}$. The nutritional value of the meals was then assessed for growing pigs.

\section{EXPERIMENTAL}

\section{Dietary components}

The chemical composition of the wheats, lupin (cv. Uniharvest and Unicrop)-seed meals and soya-bean meals used in Expts 1 and 2 are presented in Table 1. Lysine availabilities (determined with a slope-ratio assay with growing pigs) in the two lupin-seed meals and soya-bean meal no. 1 were $0.54,0.65$ and 0.89 respectively (Batterham et al. 1984). 
Table 2. Expt 1. Composition ( $\mathrm{g} / \mathrm{kg}$ dry matter) of the diets

\begin{tabular}{|c|c|c|c|c|}
\hline Diet no... & $\begin{array}{c}1 \\
\text { Lupin } \\
\text { (Lupinus } \\
\text { angustifolius) }\end{array}$ & $\begin{array}{c}2-5^{*} \\
\text { Heated } \\
\text { lupin }\end{array}$ & $\begin{array}{c}6 \\
\text { Lupin } \\
+ \\
\text { lysine }\end{array}$ & $\begin{array}{c}7 \\
\begin{array}{c}\text { Soya-bean } \\
\text { meal }\end{array}\end{array}$ \\
\hline \multicolumn{5}{|l|}{ Ingredients } \\
\hline Wheat & $648 \cdot 8$ & $648 \cdot 8$ & $648 \cdot 3$ & $647 \cdot 1$ \\
\hline Lupin-seed meal & $299 \cdot 1$ & $299 \cdot 1$ & $298 \cdot 9$ & - \\
\hline Soya-bean meal & - & - & - & $159 \cdot 0$ \\
\hline L-Lysine monohydrochloride & - & - & $5 \cdot 5$ & - \\
\hline Minerals and vitamins $\dagger$ & $5 \cdot 2$ & $5 \cdot 2$ & $5 \cdot 2$ & $5 \cdot 2$ \\
\hline Bone meal & $31 \cdot 1$ & $31 \cdot 1$ & $31 \cdot 1$ & $31 \cdot 0$ \\
\hline Maize oil & $11 \cdot 0$ & $11 \cdot 0$ & $11 \cdot 0$ & $52 \cdot 9$ \\
\hline Solkafloc & - & - & - & $54 \cdot 7$ \\
\hline Starch & $4 \cdot 8$ & 4.8 & - & $50 \cdot 1$ \\
\hline \multicolumn{5}{|l|}{ Chemical composition $\neq$} \\
\hline Lysine & $7 \cdot 5$ & $7 \cdot 5$ & $11 \cdot 8$ & $7 \cdot 5$ \\
\hline Available lysine (estimated) & $4 \cdot 9$ & - & $9 \cdot 2$ & $6 \cdot 5$ \\
\hline
\end{tabular}

* For details of heat treatment, see below.

† Contributed ( $/ \mathrm{kg}$ diet): iron $66 \mathrm{mg}$, zinc $110 \mathrm{mg}$, manganese $33 \mathrm{mg}$, copper $5.5 \mathrm{mg}$, iodine $2.2 \mathrm{mg}$, selenium $0.17 \mathrm{mg}$, sodium chloride $2.8 \mathrm{~g}$, retinol equivalent $1060 \mu \mathrm{g}$, cholecalciferol $13 \mu \mathrm{g}, \alpha$-tocopherol $22 \mathrm{mg}$, thiamin $1.1 \mathrm{mg}$, riboflavin $3.3 \mathrm{mg}$, nicotinic acid $15 \mu \mathrm{g}$, pantothenic acid $11 \mathrm{mg}$, pyridoxine $1.7 \mathrm{mg}$, cyanocobalamin $17 \mu \mathrm{g}$, pteroylmonoglutamic acid $2.2 \mathrm{mg}$, choline $552 \mathrm{mg}$, ascorbic acid $11 \mathrm{mg}$, biotin $0 \cdot 1 \mathrm{mg}$, arsanilic acid $100 \mathrm{mg}$.

$\$$ The moisture contents of the air-dry diets $(\mathrm{g} / \mathrm{kg})$ were : diet nos. $1-6,94$; diet no. 7,92 .

\section{Expt 1}

Preparation of lupin-seed meals. Lupin seed was placed to a depth of approximately $70 \mathrm{~mm}$ in wire trays and heated in a forced-draught oven to temperatures of 105, 120,135, and $150^{\circ}$ for $15 \mathrm{~min}$. The actual times taken to reach the desired temperatures increased considerably with increasing final temperature and were approximately 60, 80, 120 and $180 \mathrm{~min}$ to reach $105,120,135$ and $150^{\circ}$ respectively. After heating, the seeds were cooled and coarsely crushed through a hammer mill before incorporation into diets.

Diets. The basal diet (Table 2) was formulated from wheat and lupin-seed meal to contain $7.5 \mathrm{~g}$ lysine and $15.9 \mathrm{MJ}$ digestible energy $/ \mathrm{kg}$ dry matter (DM). All other essential amino acids were adequate, relative to the balance recommended by the (UK) Agricultural Research Council (1981).

Soya-bean meal was used as a positive control (diet 7), and was formulated to a similar lysine, crude fibre (addition of Solkafloc) and digestible energy basis as diet 1 .

The available lysine contents of the lupin-seed and soya-bean meal diets were estimated at 4.9 and $6.5 \mathrm{~g} / \mathrm{kg}$ DM. These values are based on slope-ratio values of 0.54 and 0.89 for the availability of lysine in lupin-seed meal no. 1 and soya-bean meal no. 1 respectively (Batterham et al. 1984) and an estimated ileal digestibility of lysine of 0.84 for the wheat (Taverner et al. 1981).

L-Lysine monohydrochloride was added to diet 6 (containing lupin-seed meal) to verify that lysine was the limiting amino acid in the lupin-seed meal diets. The amount added $(4.3 \mathrm{~g} / \mathrm{kg} \mathrm{DM})$ provided a surplus over that needed to equalize the estimated available lysine contents in the lupin-seed and soya-bean meal diets.

The heat treatments resulted in lower moisture contents in the lupin-seed meals. Accordingly, their DM contents were assessed after crushing and the diets were formulated on a DM basis. 
Table 3. Expt 2. Composition ( $\mathrm{g} / \mathrm{kg}$ dry matter) of the diets

\begin{tabular}{|c|c|c|c|c|}
\hline Diet no.... & $\begin{array}{c}1 \\
\text { Lupin } \\
\text { (Lupinus } \\
\text { angustifolius) }\end{array}$ & $\begin{array}{l}2 \sim 6^{*} \\
\text { Heated } \\
\text { lupin }\end{array}$ & $\begin{array}{c}7 \\
\text { Lupin } \\
+ \\
\text { lysine }\end{array}$ & $\begin{array}{c}8 \\
\begin{array}{c}\text { Soya-bean } \\
\text { meal }\end{array}\end{array}$ \\
\hline \multicolumn{5}{|l|}{ Ingredients } \\
\hline Wheat & $552 \cdot 4$ & 552.4 & $552 \cdot 2$ & $546 \cdot 7$ \\
\hline Lupin-seed meal & $395 \cdot 1$ & $395 \cdot 1$ & $395 \cdot 0$ & - \\
\hline Soya-bean meal & - & - & - & $215 \cdot 6$ \\
\hline L-Lysine monohydrochloride & - & - & $2 \cdot 0$ & - \\
\hline DL-Methionine & $1 \cdot 3$ & $1 \cdot 3$ & $1 \cdot 3$ & $0 \cdot 3$ \\
\hline L-Tryptophan & 0.3 & $0 \cdot 3$ & $0 \cdot 3$ & $0 \cdot 1$ \\
\hline Minerals and vitamins $\dagger$ & $5 \cdot 2$ & $5 \cdot 2$ & $5 \cdot 2$ & $5 \cdot 2$ \\
\hline Bone meal & $31 \cdot 2$ & $31 \cdot 2$ & $31 \cdot 2$ & $30 \cdot 9$ \\
\hline Soya-bean oil & $11 \cdot 1$ & $11 \cdot 1$ & $11 \cdot 1$ & $76 \cdot 8$ \\
\hline Solkafloc & - & - & - & $72 \cdot 0$ \\
\hline Starch & 3.4 & 3.4 & 1.7 & $52 \cdot 4$ \\
\hline \multicolumn{5}{|l|}{ Chemical composition +} \\
\hline Lysine & $9 \cdot 1$ & $9 \cdot 1$ & $10 \cdot 6$ & $9 \cdot 0$ \\
\hline Available lysine (estimated) & 6.4 & - & $8 \cdot 0$ & 7.9 \\
\hline
\end{tabular}

* For details of heat treatments, see p. 173.

+ For composition, see Table 2.

$\ddagger$ The moisture contents of the air-dry diets were $(\mathrm{g} / \mathrm{kg})$ : diet nos. $1-7,98$; diet no. 8,89 .

Assessment of performance. The seven diets were arranged in a randomized block design. The pigs were blocked on 7-week weight, sex and position in the experimental facilities. There were twelve blocks, six containing males and six females, all of the Large White breed. The pigs were penned individually and water supplied by 'nipple' drinkers. Dietary treatments were introduced when the pigs reached $20 \mathrm{~kg}$ live weight.

The diets were offered at a daily rate of $900 \mathrm{~g}$ DM at $20 \mathrm{~kg}$ live weight, with $90 \mathrm{~g}$ increments $/ 2.5 \mathrm{~kg}$ live-weight gain. The pigs were fed eight times daily, at intervals of $3 \mathrm{~h}$, with a solenoid-controlled automatic frequent feeder to ensure full utilization of added free amino acids (Batterham \& Murison, 1981). The food was offered dry. Rations were adjusted after the weekly weighings of the pigs.

The pigs were slaughtered after reaching a minimum live weight of $45 \mathrm{~kg}$ and hot eviscerated carcass weights recorded. The ham was dissected and the lean content used as an indicator of carcass leanness. Pig response was assessed in terms of daily live-weight gain, food conversion ratio ( $\mathrm{kg}$ food eaten $/ \mathrm{kg}$ live-weight gain; FCR), dressing proportion (hot carcass weight as a proportion of live weight), $P_{2}$ backfat thickness, lean content of the ham, carcass gain $/ \mathrm{d}(\mathrm{kg}$ hot carcass weight $-(\mathrm{kg}$ initial live weight $\times 0.69) /$ period $(\mathrm{d})$ on experiment) and FCR on a carcass basis ( $\mathrm{kg}$ food intake/( $\mathrm{kg}$ hot carcass weight $-(\mathrm{kg}$ initial live weight $\times 0.69)$ )). The factor of 0.69 for estimated carcass weight was previously determined with ten piglets (five males and five females) slaughtered at $20 \mathrm{~kg}$ live weight.

The results were analysed by analysis of variance and responses to heating lupin seed (diets 1-5) separated into linear and quadratic components. A value of $90^{\circ}$ was assigned to the unheated control (diet 1) as this was believed to be slightly below the threshold of the heat effect. The comparison of unheated lupin-seed meal with soya-bean meal, and the response to lysine supplementation were assessed by least significant difference (LSD). 
Expt 2

Preparation of lupin-seed meals. Lupin seed was placed to a depth of approximately $90 \mathrm{~mm}$ in wire trays and autoclaved at $121^{\circ}$ for $5,15,25,35$ or $45 \mathrm{~min}$. The time taken for the autoclave to reach $121^{\circ}$ was approximately $20 \mathrm{~min}$ and, after autoclaving, approximately $12 \mathrm{~min}$ to return to atmospheric pressure. The seed was then cooled, dried in a forced-draught oven at $70^{\circ}$ for $2 \mathrm{~h}$ to original air-dry weight and coarsely crushed through a hammer mill before incorporation into the diets.

Diets. The basal diet (Table 3) was formulated from wheat and lupin-seed meal to contain $9.1 \mathrm{~g}$ lysine and $16.0 \mathrm{MJ}$ digestible energy $/ \mathrm{kg} \mathrm{DM}$. All other essential amino acids were adequate, relative to the balance recommended by the UK Agricultural Research Council (1981) except for methionine, which was supplemented. A supplement of L-tryptophan was included as a precaution because of the low tryptophan status of lupin-seed protein and uncertainties with tryptophan analyses (E. S. Batterham and C. Watson, unpublished results). The formulation of the soya-bean meal control (diet 8), and addition of lysine to lupin-seed meal (diet 7) was as for Expt 1 except that only sufficient L-lysine was added to diet 7 to equalize estimated available lysine contents in the lupin-seed and soya-bean meal diets.

Assessment of performance. The allocation of pigs, assessment of performance and statistical analyses were as for Expt 1 except that, for the unheated control (diet 1), a value of zero was assigned for the time of autoclaving in the analyses.

\section{Chemical analyses}

The techniques used were as reported by Batterham et al. (1984) except for tryptophan, which was determined by the method of Hugli \& Moore (1972).

\section{RESULTS}

Expt 1. All pigs appeared healthy although minor food rejection occurred with most pigs throughout the experiment. Six pigs rejected considerable quantities of food and their performance was inferior relative to other pigs given their dietary treatments (one on diets 1, 2, 3 and 6 and two on diet 5). After slaughter, these pigs were examined and there were symptoms of Campylobacter sputorum var. mucosalis infections in their intestines. The results of these pigs were treated as missing plots in the statistical analyses.

Values for carcass gain/d and FCR on a carcass basis of pigs fed on the diet containing lupin-seed meal (diet 1$)$ were significantly inferior $(P<0.05)$ to those for pigs fed on the soya-bean meal (diet 7) (Table 4).

There were linear $(P<0.001)$, and in some cases quadratic $(P<0.001)$, depressions in gain/d and increases in FCR as a result of the application of heat to the lupin-seed meal. Lean in the ham was also depressed $(P<0.001)$ and $P_{2}$ backfat thickness increased $(P<0.05)$.

Addition of free lysine (diet 6) had no effect on gain/d whereas FCR, on both a live and carcass basis, was significantly improved $(P<0.05)$ to the level of that of the soya-bean-meal diet.

Heating, particularly at $150^{\circ}$, resulted in a decrease in some of the essential amino acids in the lupin seed and a decrease in the indirect 1-fluoro-2,4-dinitrobenzene (FDNB) 'available'-lysine content (Table 5).

Expt 2. Minor food rejection occurred with a number of pigs during the experiment. Three pigs (two on diet 2 , one on diet 7) initially grew normally to approximately $30 \mathrm{~kg}$ then lost weight and were slaughtered. One other pig (diet 7) grew poorly from $20 \mathrm{~kg}$ and was also 

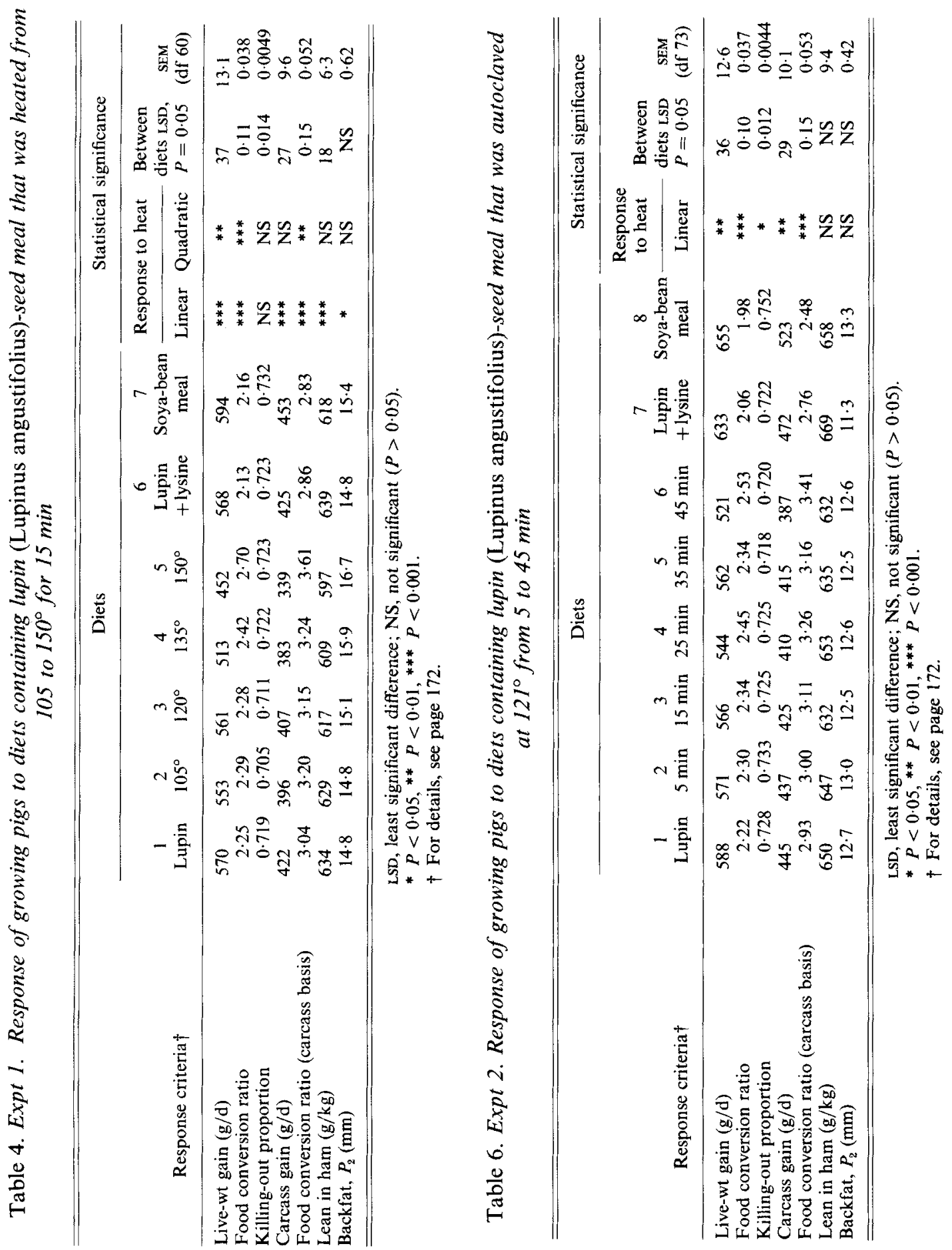
Table 5. Expt 1. Effect of heating lupin (Lupinus angustifolius) seed from 105 to $150^{\circ}$ for 15 min on the essential amino acid content $(\mathrm{g} / 16 \mathrm{~g}$ nitrogen)

\begin{tabular}{|c|c|c|c|c|c|}
\hline \multirow[b]{2}{*}{ Essential amino acids } & \multirow[b]{2}{*}{ Lupin } & \multicolumn{4}{|c|}{ Lupin seed heated at $\left(^{\circ}\right)$} \\
\hline & & 105 & 120 & 135 & 150 \\
\hline Threonine & $3 \cdot 6$ & 3.5 & $3 \cdot 2$ & $3 \cdot 2$ & $3 \cdot 2$ \\
\hline Valine & $4 \cdot 0$ & $3 \cdot 3$ & $3 \cdot 2$ & $3 \cdot 0$ & $3 \cdot 1$ \\
\hline Cystine* & - & - & - & $1 \cdot 6$ & $1 \cdot 6$ \\
\hline Methionine* & - & - & - & $0 \cdot 3$ & 0.9 \\
\hline Isoleucine & $4 \cdot 0$ & $3 \cdot 5$ & $3 \cdot 4$ & $3 \cdot 4$ & $3 \cdot 5$ \\
\hline Leucine & $7 \cdot 5$ & $6 \cdot 6$ & 6.7 & $5 \cdot 7$ & $6 \cdot 3$ \\
\hline Tyrosine & $3 \cdot 6$ & $3 \cdot 6$ & $3 \cdot 9$ & $3 \cdot 8$ & $4 \cdot 5$ \\
\hline Phenylalanine & $3 \cdot 5$ & $3 \cdot 7$ & $3 \cdot 9$ & $3 \cdot 4$ & $4 \cdot 0$ \\
\hline Histidine & $3 \cdot 0$ & $3 \cdot 0$ & 2.6 & $2 \cdot 6$ & $2 \cdot 6$ \\
\hline Lysine & $5 \cdot 1$ & $4 \cdot 8$ & $4 \cdot 6$ & $4 \cdot 5$ & $3 \cdot 7$ \\
\hline Indirect-FDNB $\uparrow$ lysine (proportion of total) & 0.97 & 0.96 & 0.97 & 0.94 & 0.86 \\
\hline
\end{tabular}

* Both the cystine and methionine concentrations were difficult to determine.

$\uparrow$ FDNB, 1-fluoro-2,4-dinitrobenzene.

slaughtered. Post-mortem examinations indicated symptoms of Campylobacter sputorum var. mucosalis infection. Their results were treated as missing plots in the statistical analyses.

Gain/d and FCR on both a live and carcass basis were significantly inferior $(P<0.05)$ for pigs fed on lupin-seed meal (diet 1) relative to soya-bean meal (diet 8) (Table 6). Heating lupin seed resulted in linear depressions in gain/d and increased FCR on both a live and carcass basis.

The addition of free lysine to diet 7 (containing unheated lupin-seed meal) increased live-weight gain/d and decreased FCR on both a live and carcass basis. However, performance on a carcass basis was still inferior $(P<0.05)$ to diet 8 (containing soya-bean meal).

Autoclaving lupin seeds had little effect on their essential amino acid content but there were small decreases in the indirect FDNB-'available'-lysine content (Table 7).

\section{DISCUSSION}

The lack of a positive response when lupin seed is subjected to both dry and moist heat indicates that there were no heat-labile anti-nutritional factors present in the seed. Therefore, these factors are not responsible for the low lysine availability in the meals for pigs. The lack of a positive response to heat also indicates that denaturing of the protein molecule has no beneficial effect as suggested by the in vitro digestibility studies with trypsin and pepsin (Cerletti, 1983). Our results are in agreement with those of Hudson (1979) who reported high in vitro digestibilities for lupin-seed meals $(0.94-0.96)$ incubated with pepsin and trypsin.

The linear and, in some cases, quadratic depressing effects in pig response as a result of the application of heat appears to be due to denaturing of the protein. The results in Tables 5 and 7 indicate that dry heat particularly resulted in an initial depression in total lysine (and other amino acid) contents. As the degree of heat increased there were indications of binding of the free $\epsilon$-amino group of lysine as the indirect-FDNB assay values decreased. This indicates that the availability of the lysine was also being reduced. However, the 
Table 7. Expt 2. Effect of autoclaving lupin (Lupinus angustifolius) seed at $121^{\circ}$ from 5 to 45 min on the essential amino acid content ( $\mathrm{g} / 16 \mathrm{~g}$ nitrogen)

\begin{tabular}{|c|c|c|c|c|c|c|}
\hline \multirow[b]{2}{*}{ Essential amino acids } & \multirow[b]{2}{*}{ Lupin } & \multicolumn{5}{|c|}{ Lupin seed autoclaved for (min) } \\
\hline & & 5 & 15 & 25 & 35 & 45 \\
\hline Threonine & $3 \cdot 6$ & $3 \cdot 2$ & $4 \cdot 0$ & 3.9 & $3 \cdot 5$ & $3 \cdot 4$ \\
\hline Valine & $3 \cdot 7$ & $3 \cdot 2$ & $3 \cdot 7$ & $3 \cdot 8$ & $3 \cdot 3$ & $3 \cdot 3$ \\
\hline Cystine & $3 \cdot 3$ & $2 \cdot 1$ & $3 \cdot 2$ & $3 \cdot 1$ & $2 \cdot 1$ & $2 \cdot 1$ \\
\hline Methionine & 0.6 & 0.6 & 0.9 & 0.9 & 0.7 & 0.5 \\
\hline Isoleucine & $4 \cdot 0$ & $3 \cdot 3$ & $4 \cdot 3$ & $4 \cdot 2$ & $3 \cdot 5$ & $3 \cdot 9$ \\
\hline Leucine & $6 \cdot 3$ & $6 \cdot 0$ & 6.9 & $6 \cdot 7$ & $5 \cdot 7$ & 6.0 \\
\hline Tyrosine & $3 \cdot 4$ & $3 \cdot 1$ & 3.6 & $3 \cdot 5$ & $3 \cdot 2$ & $3 \cdot 2$ \\
\hline Phenylalanine & $3 \cdot 8$ & $3 \cdot 1$ & $3 \cdot 7$ & $3 \cdot 5$ & $3 \cdot 2$ & $3 \cdot 6$ \\
\hline Histidine & $3 \cdot 2$ & $3 \cdot 2$ & $3 \cdot 5$ & $3 \cdot 3$ & 3.0 & 3.0 \\
\hline Lysine & $4 \cdot 6$ & $4 \cdot 7$ & $5 \cdot 3$ & $5 \cdot 0$ & $4 \cdot 4$ & $4 \cdot 4$ \\
\hline Indirect-FDNB* lysine (proportion of total) & 0.96 & 0.95 & 0.95 & 0.94 & 0.92 & 0.92 \\
\hline
\end{tabular}

* FDNB, 1-fluoro-2,4-dinitrobenzene.

indirect-FDNB values were not related to the overall lysine availabilities for pigs, as assessed by slope-ratio assays $(0.54$ and 0.65 in the unheated lupin-seed meals respectively).

The response in FCR to free lysine supplementation in both experiments indicated that lysine was limiting in the diets. However, the inability of the lysine supplement to overcome the differences in performance of pigs fed on the diets containing lupin-seed meal relative to those fed on soya-bean meal indicates that either some other nutrient became limiting or that a factor or factors within the lupin-seed meal inhibited the utilization of the free lysine supplement. It is doubtful that another essential amino acid became limiting as even if the availabilities of the other essential amino acids in lupin-seed meal were similar to that of lysine, the ratio of available essential amino acids was adequate for all amino acids for diet 7 in Expt 2, and only methionine was marginal in diet 6 for Expt $1(0.22$ instead of 0.25 , with cystine in surplus). If there was a factor or factors within the lupin-seed meal inhibiting free lysine utilization then it would have to be nonheat labile as there was no response to the application of heat.

The minor food rejection which occurred in both experiments, together with the results of the post-mortem examinations indicates that some pigs were affected by Campylobacter sputorum var. mucosalis. Symptoms of Campylobacter infection were more visible in the pigs slaughtered at the time of weight loss during Expt 2 compared with those pigs slaughtered at the completion of Expt 1, possibly due to regeneration of gut tissue following infection with the latter. The infections appeared random and unrelated to treatment effects.

In Expt 2 particularly, pigs fed on lupin-seed meal had lower killing-out proportions than pigs fed on soya-bean meal. Lupin-seed meal accumulates in the hind-gut of pigs and it is essential that results be assessed on a carcass rather than a live-weight basis. In both experiments, the differences between the lupin-seed meal and soya-bean meal diets were substantially greater on a carcass compared with live-weight basis.

Overall, the results indicate that there are no heat-labile anti-nutritional factors present in lupin seed for pigs. Nor is there any apparent benefit in applying heat to the seed in terms of denaturing the protein to improve proteolytic enzymic activity. The low lysine availability in lupin-seed meal for pigs may be due to the lysine being in a form that is inefficiently utilized. There is evidence that forms of lysine can vary in their nutritional value. For 
example, $\epsilon$ - $N$-propionyl-L-lysine has been shown to have no nutritional value for rats (Bjarnason \& Carpenter, 1969) but can be utilized by chicks (Varnish \& Carpenter, 1975). Rats absorb propionyl lysine, as it is excreted in their urine (Bjarnason \& Carpenter, 1969), but lack the kidney enzyme, $\epsilon-N$-lysine acylase, which the chick has, to utilize it (Varnish \& Carpenter, 1975). In addition, Hurrell et al. (1976) reported that reduced ileal nitrogen digestibility only partly accounted for the much larger reduction in nutritive value when heat-damaged chick muscle was fed to rats. Alternatively, if the absorbed lysine is efficiently utilized, then lupin-seed meal may contain an unidentified growth inhibitor. Such a factor would appear to be resistant to heat and specific to pigs as the availabilities of lysine for chicks (E. S. Batterham and E. J. Major, unpublished results) and rats (Batterham et al. 1984) were high.

The authors thank Messrs N. R. Thompson, A. W. Davis and H. M. Essery for skilled technical assistance and Miss E. Belinda Dettman and Mr R. E. Darnell for statistical analyses. This work was supported by financial grants from the Australian Pig Industry Research Committee.

\section{REFERENCES}

Agricultural Research Council (1981). The Nutrient Requirements of Pigs. Slough: Commonwealth Agricultural Bureaux.

Batterham, E. S. \& Murison, R. D. (1981). British Journal of Nutrition 46, 87-92.

Batterham, E. S., Murison, R. D. \& Andersen, L. M. (1984). British Journal of Nutrition 51, 85-99.

Bjarnason, J. \& Carpenter, K. J. (1969). British Journal of Nutrition 23, 859-868.

Cerletti, P. (1983). In Developments in Food Proteins, vol. 2, pp. 133-171 [B. J. F. Hudson, editor]. Barking: Applied Science Publishers.

Hill, G. D. (1977). Nutrition Abstracts and Reviews 47, 511-529.

Hudson, B. J. F. (1979). Qualitas Plantarum - Plant Foods for Human Nutrition 29, $245-251$.

Hugli, T. E. \& Moore, S. (1972). Journal of Biological Chemistry 247, 2828-2834.

Hurrell, R. F., Carpenter, K. J., Sinclair, W. J., Otterburn, M. S. \& Asquith, R. S. (1976). British Journal of Nutrition 35, 383-395.

Taverner, M. R., Hume, I. D. \& Farrell, D. J. (1981). British Journal of Nutrition 46, 159-171.

Varnish, S. A. \& Carpenter, K. J. (1975). British Journal of Nutrition 34, 325-337. 